\title{
EARLY COMPLICATIONS IN PEDIATRIC HEMATOPOIETIC STEM CELL TRANSPLANTATION
}

Carla Nolasco Monteiro Breviglieri ${ }^{1,2}$, Natalia Maria Tavares Ferreira Borges ${ }^{3,4}$, Gabriele Zamperlini Netto ${ }^{1,5}$, Alessandra Araujo Gomes ${ }^{1,6}$

\section{Instituto de Tratamento do Câncer Infantil (ITACI) - Instituto da Criança - Hospital das Clínicas da Universidade de São Paulo, São Paulo-SP}

2. Hospital Samaritano, São Paulo-SP

3. Hospital São Rafael, Salvador-BA

4. Hospital Martagão Gesteira, Salvador-BA

5. Hospital Israelita Albert Einstein, São Paulo-SP

6. Hospital Sírio-Libanês, São Paulo-SP

Correspondence to: Alessandra Araujo Gomes (ale_a_gomes@hotmail.com)

\section{INTRODUCTION}

Hematopoietic stem cell transplantation (HSCT) has the potential to cure a significant proportion of patients with malignant and nonmalignant diseases. The high doses of chemotherapy and/or radiotherapy included in conditioning regimens affect all organs and tissues, producing several early and late complications.

The most common early effects are nausea, vomiting and mucositis. Other early complications, less frequent, but cause of morbidity and mortality are hemorrhagic cystitis, sinusoidal obstruction syndrome, thrombotic microangiopathy, capillary leak syndrome, engraftment syndrome, diffuse alveolar hemorrhage, idiopathic pneumonia syndrome.

\section{NAUSEA/VOMITING}

The conditioning regimens used in HSCT are known to have a high emetogenic risk. Nausea and vomiting are some of the most feared adverse effects of chemotherapy and radiotherapy. Studies show that administering prophylactic regimens concordant with published guidelines significantly reduces and controls symptoms for patients receiving moderately or highly emetogenic treatment. Focused on the prevention, guidelines recommend a combination of aprepitant, dexamethasone and a serotonin antagonist in pediatric patients. ${ }^{2,4}$

Emetogenic potential of intravenous antineoplastic agents

\begin{tabular}{|c|c|}
\hline Probability of vomiting & Agent \\
\hline High & $\begin{array}{c}\text { Busulfan IV } \geq 0,8 \mathrm{mg} / \mathrm{kg} / \text { dose } \\
\text { Cyclophosphamide IV }\left(\geq 1200 \mathrm{mg} / \mathrm{m}^{2} / \text { dose }\right) \\
\text { Melphalan IV } \\
\text { Carmustine } \\
\text { Carboplatin IV } \geq 175 \mathrm{mg} / \mathrm{m}^{2} / \text { dose } \\
\text { Cisplatin IV } \geq 12 \mathrm{mg} / \mathrm{m}^{2} / \text { dose } \\
\text { Cytarabine IV } \geq 3 \mathrm{~g} / \mathrm{m}^{2} / \text { day } \\
\text { Methotrexate IV } \geq 12 \mathrm{~g} / \mathrm{m}^{2} / \text { dose } \\
\text { Thiotepa } \geq 300 \mathrm{mg} / \mathrm{m}^{2}\end{array}$ \\
\hline Moderate & $\begin{array}{c}\text { Cyclophosphamide IV }\left(1000 \mathrm{mg} / \mathrm{m}^{2} / \text { dose }\right) \\
\text { Cytarabine IV } 75 \mathrm{mg} / \mathrm{m}^{2} / \text { dose } \\
\text { Methotrexate IV } 5 \mathrm{~g} / \mathrm{m}^{2} / \text { dose } \\
\text { Ifosfamide }\end{array}$ \\
\hline Low & $\begin{array}{c}\text { Cyclophsphamide IV } 500 \mathrm{mg} / \mathrm{m}^{2} / \text { dose } \\
\text { Mitoxantrone IV } \leq 33 \mathrm{mg} / \mathrm{m}^{2} / \text { dose } \\
\text { Etoposide } \\
\text { Methotrexate IV } \leq 90 \mathrm{mg} / \mathrm{m} 2 / \text { dose } \\
\text { Procarbazine PO }\end{array}$ \\
\hline Minimal & $\begin{array}{c}\text { Fludarabine } \\
\text { Vincristine IV } \leq 1,5 \mathrm{mg} / \mathrm{m}^{2} / \text { dose }\end{array}$ \\
\hline
\end{tabular}




\section{MUCOSITIS}

Mucositis is characterized by mucosal damage ranging from mild inflammation to extensive ulceration, which may affect the oral cavity and other parts of the gastrointestinal tract. It is seen in $75-99 \%$ of patients who had combined total body irradiation and chemotherapy. It peaks between day 6 and 12 and resolution coincides with engraftment. Oral mucositis causes disturbances in feeding, swallowing, and speaking, along with the possibility of secondary severe infection. Basic oral care consists of a pre-transplant oral/dental examination aimed at decreasing the oral infectious and inflammatory burden, and routine mouth care with bland rinses and soft toothbrush. Cryotherapy prevents oral mucositis in protocols containing high dose melphalan. Oral mucositis is often so severe that patients require parenteral narcotics for relief of pain and total parenteral nutrition. ${ }^{2,5,6}$ Oral mucositis grading scales are below:

\begin{tabular}{c|c}
\hline \multicolumn{2}{c}{ WHO SCORE } \\
\hline GRADE 0 & No objective findings, function irrelevante \\
\hline GRADE 1 & Erythema plus pain, function irrelevante \\
\hline GRADE 2 & Ulceration, ability to eat solids \\
\hline GRADE 3 & Ulceration, ability to eat liquids \\
\hline GRADE 4 & Ulceration, nothing by mouth \\
\hline
\end{tabular}

\begin{tabular}{c|c}
\hline \multicolumn{2}{c}{ WHO ORAL MUCOSITIS SCALE } \\
\hline 0 & None \\
\hline 1 & Soreness +/- erythema \\
\hline No ulceration & Erythema, ulcers \\
\hline 2 & Ulcers, extensive erythema \\
\hline Patients can swallow solid diet & \\
\hline 3 & \\
\hline Patients cannot swallow solid diet & Mucositis to the extent that alimentation is not possible \\
\hline 4 &
\end{tabular}

*Adapted from WHO classification

\section{HEMORRHAGIC CYSTITIS}

Hemorrhagic cystitis is characterized by diffuse bladder inflammation and bleeding, with sustained hematuria and lower urinary tract symptoms, in the abscence of other conditions such as vaginal bleeding, bleeding diathesis, or urinary tract infection. It has significant morbidity, prolonged hospitalization and occasional mortality. Symptoms vary from microscopic to macroscopic hematuria with clots, urinary obstruction, and renal and/or bladder damage, and dysuria. $1,3,7,8$

\begin{tabular}{c|c}
\hline \multicolumn{2}{c}{ GRADING SYSTEM FOR HEMORRHAGIC CYSTITIS } \\
\hline GRADE I & Microscopic hematúria \\
\hline GRADE II & Macroscopic hematúria \\
\hline GRADE III & $\begin{array}{c}\text { Macroscopic hematuria with small clots } \\
\text { GRADE IV }\end{array}$ \\
\hline requiring instrumentation for clot evacuation
\end{tabular}

*Adapted from Decker DB et al ${ }^{7}$

\section{Etiology:}

1) Chemotherapy: alkylating agentes (especially cyclophosphamide and ifosfamide): the main metabolite, acrolein, can precipitate in the bladder, causing mucosal edema, ulceration, epithelial necrosis and submucosal fibrosis;
2) Infectious: adenovírus, cytomegalovirus, BK vírus - cytopathic effect on bladder mucosa, causing inflammation;

3) Radiotherapy: causes chronic fibrosis, endarteritis and mucosal desquamation. 


\section{Prevention:}

The three main approaches for prophylaxis of cyclophosphamide-induced hemorrhagic cystitis include mesna, hyperhydration with forced diuresis, and continuous bladder irrigation.

\section{Treatment:}

Intensive intravenous hydration, forced diuresis, analgesia, spasmolytic drugs, treatment of infections. Progression of hematuria and possibly clot retention often necessitate bladder irrigation. In more aggressive cases, it is possible to use cystoscopy, clot evacuation, and fulguration 1,3,7,8.

\section{Sinusoidal Obstruction Syndrome}

Sinusoidal obstruction syndrome (SOS), also called hepatic veno-occlusive disease (VOD), remains a complication after HSCT and belongs to a group of systemic endothelial diseases. Toxic metabolites generated by the conditioning regimen damage the sinusoidal endothelial cells and hapatocytes in zone 3 of the hepatic acinus. The first events are loss of fenestrae in endothelial cells, formation of gaps, and rouding up or swelling. Red blood cell, leukocytes and debris penetrate into the space of Disse and dissect off the sinusoidal lining. The venous lumen narrows and sinusoidal venous outflow is reduced, resulting in post-sinusoidal hypertension9-11. Risk factors are below:

\begin{tabular}{|c|c|}
\hline Transplant-related factors & $\begin{array}{c}\text { Unrelated donor } \\
\text { HLA-mismatched donor } \\
\text { Non T-cell-depleted transplant } \\
\text { Myeloablative-conditioning regimen } \\
\text { Oral or high-dose busulfan-based regimen } \\
\text { High-dose TBI-based regimen } \\
\text { Second HSCT }\end{array}$ \\
\hline $\begin{array}{l}\text { Patient and disease-related general } \\
\text { factors }\end{array}$ & $\begin{array}{c}\text { Older age } \\
\text { Karnofsky score below } 90 \% \\
\text { Metabolic syndrome } \\
\text { Female receiving norethisterone } \\
\text { Advanced disease (beyond second CR or relapse/refractory) } \\
\text { Thalassemia } \\
\text { Genetic factors (GSTM1 polymorphism, C282Y allele, MTHFR 677CC/1298CC } \\
\text { haplotype) }\end{array}$ \\
\hline Hepatic-related & $\begin{array}{c}\text { Transaminases }>2.5 \text { upper limit of normal } \\
\text { Serum bilirubin }>1.5 \text { upper limit of normal } \\
\text { Cirrhosis } \\
\text { Active viral hepatites } \\
\text { Abdominal or hepatic irradiation } \\
\text { Previous use of gemtuzumab ozogamicin or inotuzumab ozogamicin } \\
\text { Hepatotoxic drugs } \\
\text { Iron overload }\end{array}$ \\
\hline Specific pediatric risk factors & $\begin{array}{c}\text { Osteopetrosis } \\
\text { Hemophagocytic lymphohistiocitosis } \\
\text { Griscelli syndrome } \\
\text { X-linked lymphoproliferative disease } \\
\text { Neuroblastoma } \\
\text { Hemoglobinopathies } \\
\text { Infants (age }<1-2 \text { years) }\end{array}$ \\
\hline
\end{tabular}

*Adapted from Mohty M et al10 and Corbacioglu S et al 
Clinical manifestations are weight gain, fluid retention with ascites and anasarca, painful hepatomegaly, jaundice, consumption of platelets (it is usually one of the earliest signs in children) and multi-organ dysfunction in severe cases with pleural effusion, renal failure and encephalopathy9-11. Differences between children and adults are below:

\begin{tabular}{|c|c|c|}
\hline CRITERIA & CHILDREN & ADULTS \\
\hline INCIDENCE & $\begin{array}{c}\text { Approximately } 20 \% \\
\text { Up to } 60 \% \text { in high-risk patients }\end{array}$ & Approximately $10 \%$ \\
\hline RISK FACTORS & $\begin{array}{c}\text { Additional pediatric factors: } \\
\text {-Infants } \\
\text { - Pediatric/genetic diseases with incidences above } \\
\text { average }\end{array}$ & Established risk factors \\
\hline CLINICAL PRESENTATION & $\begin{array}{c}\text { Late-onset in } 20 \% \\
\text { Anicteric in } 30 \% \\
\text { Hyperbilirubinemia, if present: } \\
\text {-Is frequently pre-existent } \\
\text {-Occurs late during SOS } \\
\text {-Is typical of severe SOS }\end{array}$ & $\begin{array}{l}\text { Late-onset is rare } \\
\text { Anicteric is rare }\end{array}$ \\
\hline $\begin{array}{l}\text { NEED FOR PROPER ASSESSMENT OF } \\
\text { ASCITES AND HEPATOMEGALY }\end{array}$ & $\begin{array}{l}\text { High incidence of disease-related hepatomegaly and } \\
\text { ascites pre-HSCT }\end{array}$ & \\
\hline TREATMENT & $\begin{array}{l}\text { Defibrotide for severe SOS with multi-organ } \\
\text { dysfunction/failure was associated with better } \\
\text { results in children }\end{array}$ & \\
\hline PREVENTION & $\begin{array}{l}\text { Defibrotide demonstrated efficacy for prevention in } \\
\text { children in a randomized prospective trial }\end{array}$ & \\
\hline
\end{tabular}

${ }^{*}$ Adapted from Corbacioglu S et al ${ }^{11}$

The diagnostic criteria recently published by European Society for Blood and Marrow Transplantation (EBMT) are below:

\section{EBTM diagnostic criteria for hepatic SOS in children}

-No limitation for time onset of SOS

The presence of two or more of the following:

-Unexplained consumptive and transfusion-refractory thrombocytopenia

-Otherwise unexplained weight gain on three consecutive days despite the use of diuretics or a weight gain $>5 \%$ above baseline value

-Hepatomegaly (best if confirmed by imaging) above baseline value

-Ascites (best if confirmed by imaging) above baseline value

-Rising bilirubin from a baseline value on 3 consecutive days or bilirubin $>2 \mathrm{mg} / \mathrm{dL}$ within $72 \mathrm{~h}$ 
Diagnostic imaging is complementary. Ultrasonography (US) is more available, and as a bedside tool. Computed tomography and magnetic resonance imaging can substitute for or complement US. The most common findings are hepatomegaly, ascites, hepatic artery resistive index, velocity of portal venous flow, increased periportal echogenicity and increased hepatic echotexture, and gallbladder wall thickening. Doppler US assesses hepatic and portal vascular flow, pressure abnormalities and hepatic arterial early acceleration indices. Portal venous flow reversal (hepatofugal flow) are not consistently present or are a late finding, and might therefore be useful for the assessment of severity rather than early diagnosis. ${ }^{11}$

Severe SOS resulting in multi-organ dysfunciton/failure, EBMT criteria for grading the severity is below:

\begin{tabular}{|c|c|c|c|c|}
\hline CRITERIA & MILD (1) & MODERATE (2) & SEVERE (3) & VERY SEVERE (4) \\
\hline $\begin{array}{l}\text { Liver } \\
\text { function test }\end{array}$ & $<2 x$ normal & $>2$ and $<5 x$ normal & $>5$ & $>5$ \\
\hline $\begin{array}{l}\text { Persistent refractory } \\
\text { thrombocytopenia }\end{array}$ & $<3$ days & 3-7 days & $>7$ days & $>7$ days \\
\hline Bilirubin (mg/dL) & $<2$ & $<2$ & $>2$ & $>2$ \\
\hline Ascites & Minimal & Moderate & $\begin{array}{l}\text { Necessity for } \\
\text { paracentesis }\end{array}$ & Necessity for paracentesis \\
\hline Bilirubin kinetics & & & & Doubling within $48 \mathrm{~h}$ \\
\hline Coagulation & Normal & Normal & $\begin{array}{l}\text { Impaired } \\
\text { coagulation }\end{array}$ & Impaired coagulation \\
\hline Renal function (mL/min) & $89-60$ & $59-30$ & $29-15$ & <15 (renal failure) \\
\hline $\begin{array}{l}\text { Pulmonary function (oxygen } \\
\text { requirement) }\end{array}$ & $<2 \mathrm{~L} / \mathrm{min}$ & $>2 \mathrm{~L} / \mathrm{min}$ & $\begin{array}{l}\text { Invasive pulmonar } \\
\text { ventilation } \\
\text { (including } \\
\text { CPAP) }\end{array}$ & \\
\hline Central nervous system & Normal & Normal & Normal & $\begin{array}{l}\text { New onset cognitive } \\
\text { impairment }\end{array}$ \\
\hline
\end{tabular}

*Adapted from Corbacioglu S et al ${ }^{1}$

Prophylaxis for SOS includes reducing iron overload, use reduced intensity conditioning regimen if possible, busulfan pharmacokinetic monitoring, avoid acute fluid overload. For those patients receiving a busulfan(Bu)-cyclophosphamide(Cy) regimen, studies show that the order of application of Cy and Bu as impact on lower incidence of SOS. Ursodeoxycholic acid reduces hydrophobic bile acids, which can be toxic to hepatic parenchymal cells, and randomized trials demonstrate a reduced risk of SOS in transplant patients. Heparin is not suggested for prophylaxis in adults, but some studies showed a significant reduction in SOS in children. ${ }^{12-15}$

The treatment includes supportive care (restriction of fluids, diuretics, and renal replacement in severe cases) and use of Defibrotide $(6.25 \mathrm{mg} / \mathrm{kg} / \mathrm{dose}, 4$ times a day). Corticosteroids can be used in some cases where Defibrotide is not available or in combination with Defibrotide in severe cases. The initial dose is $500 \mathrm{mg} / \mathrm{m} 2 /$ dose every 12 hours for six doses and gradual reduction. . $^{12,16}$

Implementation of the new criteria for diagnosis and assessment of the severity of SOS allowed earlier identification of patients in need of intervention for the better treatment of SOS.

\section{Transplant-Related Thrombotic Microangiopathy}

Transplant-related thrombotic microangiopathy (TATAM) is a side effect that usually occurs in the first 
100 days after hematopoietic stem cell transplantation (HSCT), with undetermined incidence and more frequently reported in allogeneic bone marrow transplantation. ${ }^{17}$ TA-TAM corresponds to a clinical syndrome resulting from endothelial injury, with platelet activation and microthrombi deposition at the capillary level, which may lead to consequent ischemic injury of several organs and microangiopathic hemolytic anemia. It presents a wide variety of severity levels, and there may be mild self-limited conditions up to multiple organ dysfunction with mortality up to $80 \%$.

The pathogenesis of TA-TAM is not fully understood yet, however, it is known that endothelial injury plays a central role in its origin. During an early period of HSCT, several factors may lead to a hypercoagulable states in the endothelium due to collagen exposure and tissue factor activation, such as, conditioning regimen, use of colony growth factors, HLA incompatibility, long period of immobility and infections. This scenario leads to a second phase, which causes further endothelial injury and starts platelet aggregation, abnormal activation of the complement and thrombus formation in microvessels. At this time, the use of calcineurin inhibitors, especially when associated with mTOR inhibitors, in addition to GVHD and infectious conditions are the main responsible for the endothelial injury ${ }^{17}$. Abnormal activation of the classical and alternative complement pathway causes endothelial damage, propagating its dysfunction. ${ }^{18,19}$

The kidney is the main target organ, also accompanied by gastrointestinal tract, heart, lungs and central nervous system. The main signs include in- creased creatinine serum level, proteinuria and hypertension, nonspecific conditions that also can happen in patients without TA-TAM. Impaired renal function may not be present, but its absence should not exclude the diagnosis. Signs of pulmonary hypertension, headache, diarrhea, vomiting, abdominal pain, gastrointestinal bleeding and pericardial effusions may be the predominant symptoms, and therefore they should be highly suspicious 18 .

The most common and early clinical manifestations seen in TA-TAM are hypertension, thrombocytopenia, and increased lactate dehydrogenase serum level (LDH). Proteinuria may be also present about 10-14 days before the diagnosis of microangiopathy. Thus, patients who present risk factors should be routinely screened twice weekly LDH dosage, weekly urinalysis, and a careful follow-up of blood pressure assessment, especially in the first 100 days post- HSCT. $20,21,22$

Hypertension is a common post- HSCT side effect, however, when its levels are upper than expected while using calcineurin or steroid therapy, usually requiring $>2$ antihypertensive medications, it should increase clinical suspicion for TA-TMA and be further investigated.

The diagnosis is confirmed by biopsy of the target organ, but due to the complexity and performing risks, such evidence is hardly feasible. ${ }^{1}$ Therefore, TATAM is confirmed by using diagnostic criteria. There is a wide variety, according to the authors, in the parameters to be evaluated, which makes it difficult to evaluate its incidence. The four most used currently are described below:

\begin{tabular}{|c|c|c|c|c|}
\hline & BMT-CTN & IWG & Cho et al & Jodele et al \\
\hline Schistocytes & $>2$ Per field & $>4 \%$ & $>2$ Per field & Present \\
\hline Elevated LDH & + & + & + & + \\
\hline Thrombocytopenia & - & + & + & + \\
\hline Decreased $\mathrm{Hb}$ or increased red cell transfusion & - & + & + & + \\
\hline Negative coombs test & + & - & + & - \\
\hline Decreased haptoglobin & - & + & + & - \\
\hline Renal and/or neurologic dysfunction & + & - & - & $\begin{array}{c}\text { Hypertension or } \\
\text { proteinuria }\end{array}$ \\
\hline Normal coagulation studies & - & - & + & - \\
\hline Elevated soluble C5b-9 & - & - & - & + \\
\hline $\begin{array}{l}\text { Abbreviations: BMT-CTN = Bone Marrow Transplant Clinical } \\
\text { Trials Network; Hb =hemoglobin; IWG =International Working } \\
\text { Group; } \mathrm{LDH}=\text { =lactate dehydrogenase; TA-TMA = transplant- } \\
\text { associated thrombotic microangiopathy;' }{ }^{\prime}=\text { required; }{ }^{\prime} \text { - }^{\prime} \\
=\text { not specified }\end{array}$ & & & & \\
\hline
\end{tabular}

*Adapted from Khosla J et al ${ }^{18}$ 
It is important to rule out others conditions that can be similar to TA-TAM, as sinusoidal obstruction syndrome, autoimmune hemolytic anemia and other types of microangiopathy, like thrombotic thrombocytopenic purpura (TTP) and hemolytic uremic syndrome (HUS) ${ }^{20}$.

The factors associated with worst severity in TATAM are the presence of proteinuria and evidence of activation of the complement terminal pathway (increased dosage of C5b-9) showing survival rates under $20 \%$ when two factors are present, however, the last mentioned is not performed in Brazill ${ }^{21,23}$. Another easy to be performed parameter, which can help predict prognosis, is the TAM index based on the relation of $\mathrm{LDH}$ (in $\mathrm{U} / \mathrm{L}$ ) by platelet count (in $x 109 / L$ ), which when $\geq 100$ is associated with lower survival ${ }^{20,24}$.

Since fast start of therapy leads to better survival rates and long-term outcomes, regular screening and early diagnosis are important. Initial treatment is based on reducing the factors that can induce TATAM, and should be promptly performed by treating infections and GVHD, in addition to discontinuation of calcineurin inhibitors. However, the change of immunosuppressors in the presence of GVHD should be done with precaution, since its reactivation can lead to worsening of the microangiopathy scenario. In addition, hypertension should be strictly controlled by the risk of posterior reversible encephalopathy syndrome (PRES).

The benefit of plasmapheresis is controversial, being described only in small cohorts ${ }^{25}$. Most studies describe low survival rates despite the initial response to it26. If performed, its early onset seems to be associated with better survival, especially when there is still no target organ injury ${ }^{25,27}$. Initially, daily sessions should be performed for at least 2 weeks, with subsequent gradual pause according to clinical and laboratory response. Rituximab can be used alone or in association with plasmapheresis and is especially effective in the presence of antibodies.

The use of eculizumab, an inhibitor of the complement terminal pathway, is associated with better results and survival ${ }^{28,29}$ and should by choice be used in all high-risk cases (proteinuria $>2 \mathrm{mg} / \mathrm{mg}$ or target organ injury - C5b-9 dosage not performed in Brazil). In the disease displayed by gastrointestinal bleeding, doses of eculizumab with shorter pauses (up to alternate days vs weekly) should be used29. Attention should be given to a higher risk of encap- sulated bacteria infections related to its use, and antimicrobial prophylaxis should be established. In general, the discontinuation of eculizumab use after induction and maintenance phases is not associated with reactivation of the disease.

Several reports have been made regarding the benefit of the use of defibrotide in the treatment of TATAM20.

Currently, prophylaxis with $\mathrm{N}$-acetylcysteine and omega $^{3}$ has been described as effective in reducing the incidence of TA-TAM with the rates in the pediatric high-risk population falling from $28.2 \%$ to $4.5 \% 30$.

\section{CAPILLARY LEAK SYNDROME}

Capillary leak syndrome is characterized by the loss of intravascular fluids into interstitial spaces and is triggered by a combination of inflammation and endothelial damage. Patients presents sudden weight gain, generalized edemas (ascites, pleural effusion, pericarditis) unresponsive to diuretic treatment, and hypotension eventually leading to cardiovascular shock with respiratory and pre-renal insufficiency. It is mainly observed in children, although true incidence is unknown (some series: $5 \%)^{1,3,31}$.

Diagnostic criteria include: early after HSCT (days +10 to 11 ), unexplained weight gain $>3 \%$ in $24 \mathrm{~h}$, positive intake balance despite furosemide evaluated $24 \mathrm{~h}$ after its administration. (livro EBMT)

Treatment: withdraw growth factors and supportive care (colloids, catecholamines, plasma). Corticosteroids can be used. Intravenous immunoglobulin (IVIG) and Bevacizumab (anti-VEGF) have been used in some cases with good response $e^{1,3,31}$.

\section{ENGRAFTMENT SYNDROME}

Engraftment syndrome (ES) includes a range of signs and symptoms occurring close to granulocyte recovery after stem cell transplantation is performed. ES is classically observed after autologous HSCT, although it has also been described after allo-transplantation. Several names can be given to this syndrome, as capillary leak syndrome, autoaggression syndrome (after autotransplants), aseptic shock syndrome and autologous GVHD. There is not a consent regarding the definition of ES, which makes it difficult to dictate the incidence and risk factors. There are also conflicting data regarding an association between ES, NRM and survival32-34. 
The pathophysiology of ES is poorly understood although it probably involves release of pro-inflammatory cytokines, consequence of degranulation and oxidative metabolism, and systemic endothelial damage that may ultimately result in multi-organ failure $^{35}$. In some cases, the concomitant administration of G-CSF, which is highly toxic to endothelial tissue, contributes to its development ${ }^{1}$.
Diagnosis criteria for ES typically includes fever from non-infectious etiologies and features of systemic vascular leak. The two most used diagnostic criteria were described according to Spitzer and Maiolino and are listed below.

\begin{tabular}{|c|c|c|}
\hline & Spitzer & Maiolino \\
\hline Requirements & $\begin{array}{c}3 \text { major or } 2 \text { major }+1 \text { minor within } 4 \text { days of the } \\
\text { engraftment }\end{array}$ & $\begin{array}{c}\text { major }+1 \text { minor within } 1 \text { day from presence of } \\
\text { neutrophils }\end{array}$ \\
\hline Major criteria & $\begin{array}{c}\text { - Temperature } \geq 38.3^{\circ} \mathrm{C} \text { with undefined infectious } \\
\text { etiology } \\
\text { - Erythrodermatous rash compromising } 25 \% \text { of } \\
\text { body surface area and not caused by a medication } \\
\text { - Non-cardigenic pulmonary edema, expressed } \\
\text { by diffuse pulmonary infiltrate, expected with this } \\
\text { diagnosis, and hypoxia }\end{array}$ & - Non-infectious fever \\
\hline Minor criteria & $\begin{array}{l}\text { - Hepatic impairment with either bilirubin } 2 \mathrm{mg} / \mathrm{dL} \\
\text { or transaminase serum levels twice baseline } \\
\text { - Renal insufficiency (serum creatinine twice } \\
\text { baseline } \\
\text { - Weight gain } 2.5 \% \text { of baseline body weight } \\
\text { - Transient encephalopathy unexplainable by other } \\
\text { causes }\end{array}$ & $\begin{array}{l}\text { - Skin rash } \\
\text { - Pulmonary infiltrates } \\
\text { - Diarrhea starting } 24 \text { hours before or at any time } \\
\text { after the first rise of neutrophils }\end{array}$ \\
\hline
\end{tabular}

Regardless of the criteria used to diagnose ES, it is important to distinguish ES from other complications including acute GVHD, and radiation and drug-related toxicities and infections. Whether the ES cytokine cascade contributes to the initiation of GVHD after allotransplantation or is an early manifestation of ES is unclear ${ }^{36}$.

ES may be self-limited and require no therapy. In several cases with clinically significant manifestations of vascular leak, in the absence of other etiology, treatment with corticosteroid $1 \mathrm{mg} / \mathrm{kg} /$ day as a starting dose is usually enough. ES is highly responsive to corticosteroid and treatment is given only as long as symptoms persist, which typically occurs within 2 to 3 days, followed by progressive lowering ${ }^{36,37}$.

\section{DIFFUSE ALVEOLAR HEMORRHAGE}

Diffuse alveolar hemorrhage (DAH) is probably a consequence of damage to the alveolar capillary basement membrane ${ }^{3}$. It is a non-infectious complication that occurs in up to $5 \%$ of patients post-HSCT and carries a high mortality (60-100\%). Clinical presentation is hypoxemia, dyspnea, diffuse opacities on chest radiography, and progressively bloodier bronchoalveolar lavage on bronchoscopy. Alveolar hemorrhage results from loss of integrity in the alveolar-capillary basement membrane, and accumulation of red blood cells in the alveolar space. Lung injury from conditioning regimens, total body irradiation, occult infections, and other comorbidities such as graft versus host disease, TMA, and cytokine 
release and inflammation are risk factors. Management includes supportive measures (intensive care, ventilation, optimization of fluid and electrolyte balance, correction of coagulation and prophylactic antibiotics), transfusion of blood products, corticoids. Some studies demonstrate benefits with aminocaproic acid, nebulized tranexamic acid, recombinant activated fator $\mathrm{VII}^{3,38}$.

\section{IDIOPATHIC PNEUMONIA SYNDROME}

Idiopathic pneumonia syndrome (IPS) is a rare complication following HSCT, defined by diffuse alveolar injury in the abscence of active lower respiratory tract infection, cardiac or renal dysfunction, and iatrogenic fluid overload. The incidence ranges from $2 \%$ to $15 \%$ in the first 120 days after HSCT. Some risk factors are full intensity conditioning, TBI, older age at transplant, acute GVHD, diagnosis of acute leukemia or myelodysplastic syndrome. Clinical presentation is variable but includes fever, non-productive cough, dyspnea, tachypnea and hypoxemia. X-rays or CT scans demonstrates diffuse alveolar or interstitial infiltrates. The pathogenesis is multifactorial, with endothelial cell activation and injury for toxic effect of conditioning regimens, leading to release of inflammatory cytokines, specifically TNF-alfa. The treatment includes supportive measures: oxygen therapy, ventilation (invasive or not - high-flow nasal, CPAP), empiric antimicrobials and control of fluids. Specific treatment options are corticosteroids, and Etanercept (an TNF-alfa binding protein). Despite the advances, the mortality from IPS remains high at $59-80 \%$ at 2 weeks of evoluition ${ }^{3,39}$.

\section{REFERENCES}

1. Carreras E, Diaz-Ricart M. Early complications of endothelial origin. In: Carreras E, Dufour C, Mohty M, Kröger N. ed. The EBMT Handbook: Hematopoietic Stem Cell Transplantation and Cellular Therapies. Springer Open; 2019.p.315322.

2. Masszi T, Mank A. Supportive care. In: Apperley J, Carreras E, Gluckman E, Masszi T. ed. The EBMT Handbook: Haematopoietic Stem Cell Transplantation. 6th Edition. 2012.p.156-175.

3. Carreras E. Early complications after HSCT. In: Apperley J, Carreras E, Gluckman E, Masszi T. ed. The EBMT Handbook: Haematopoietic Stem Cell Transplantation. 6th Edition. 2012.p.176-195.

4. Sing EPC, Robinson PD, Flank J, Holdsworth $M$, Thackray J et al. Classification of the acute emetogenicity of chemotherapy in pediatric patients: A clinical practice guideline. Pediatric Blood \& Cancer. 2019;66:e27646. Available from: https://doi.org/10.1002/pbc.27646.

5. Chaudhry HM, Bruce AJ, Wolf RC, Litzow MR, Hogan WJ et al. The incidence and severity of oral mucositis among allogeneic Hematopoietic Stem Cell Transplantation patients: a systematic review. Biol Blood Marrow Transplant. 2016;22:605-616. Available from: http://dx.doi. org/10.1016/j.bbmt.2015.09.014.
6. Elad S, Raber-Durlacher JE, Brennan MT, Saunders DP, Mank AP et al. Basic oral care for hematology-oncology patients and hematopoietic stem cell transplantation recipientes: a position paper from the joint task force of the Multinational Association of Supportive Care in Cancer/ International Society of Oral Oncology (MASCC) ISOO) and the European Society for Blood and Marrow Transplantation (EBMT). Support Care Cancer. 2015;23:223-236. Available from: DOI 10.1007/s00520-014-2378-x.

7. Decker DB, Karam JA, Wilcox DT. Pediatric hemorrhagic cystitis. Journal of Pediatric Urology. 2009;5:254-264. Available from: DOI 10.1016/j. jpurol.2009.02.199.

8. Kloos RQH, Boelens JJ, Jong TMVP, Versluys B, Bierings $M$. Hemorrhagic cystitis in a cohort of Pediatric Transplantations: incidence, treatment, outcome, and risk factors. Biol Blood Marrow Transplantation. 2013;19:1254-1270. Available from: http://dx.doi.org/10.1016/j. bbmt.2013.05.014.

9. Ruutu T, Carreras E. Hepatic complications. In: Carreras E, Dufour C, Mohty M, Kröger N. ed. The EBMT Handbook: Hematopoietic Stem Cell Transplantation and Cellular Therapies. Springer Open; 2019.p.373-379. 
10. Mohty M, Malard F, Abecassis M, Aerts E, Alaskar AS et al. Revised diagnosis and severity criteria for sinusoidal obstruction syndrome/ veno-occlusive disease in adult patients: a new classification from the European Society for Blood and Marrow Transplantation. Bone Marrow Transplantation. 2016;51:906-912. Available from: DOI 10.1038/bmt.2016.130.

11. Corbacioglu S, Carreras E, Ansari M, Balduzzi A, Cesaro $S$ et al. Diagnosis and severity criteria for sinusoidal obstruction syndrome/veno-occlusive disease in pediatric patients: a new classification from the European society for blood and marrow transplantation. Bone Marrow Transplantation. 2017;1-8. Available from: DOI 10.1038/bmt.2017.161.

12. Dignan FL, Wynn RF, Hadzic N, Karani N, Quaglia A et al. BCSH/BSBMT guideline: diagnosis and management of veno-occlusive disease (sinusoidal obstruction syndrome) following haematopoietic stem cell transplantation. British Journal of Haematology. 2013;163:444-457. Available from: DOI 10.1111/bjh.12558.

13. Bajwa RPS, Mahadeo KM, Taragin BH, Dvorak CC, McArthur J et al. Consensus report by Pediatric acute lung injury and sepsis investigators and Pediatric Blood and Marrow Transplantation Consortium Joint Working Committees: Supportive care guidelines for management of veno-occlusive disease in children and adolescents, part 1: focus on investigations, prophylaxis, and specific treatment. Biol Blood Marrow Transplantation. 2017;23:1817-1825. Available from: https:// doi.org/10.1016/j.bbmt.2017.07.021.

14. Rezvani AR, McCune JS, Storer BE, Batchelder A, Kida A et al. Cyclophosphamide followed by intravenous targeted busulfan for allogeneic hematopoietic cell transplantation: pharmacokinetics and clinical outcomes. Biol Blood Marrow Transplantation. 2013;19:1033-1039. Available from: http://dx.doi.org/10/1016/j. bbmt.2013.04.005.

15. Seydoux C, Medinger M, Gerull S, Halter J, Heim D et al. Busulfan-cyclophosphamide versus cyclophosphamide-busulfan as conditioning regimen before allogeneic hematopoietic cell transplantation: a prospective randomized trial. Annals of Hematology. 2021;100:209-216. Available from: https://doi.org/10.1007/s00277-020-04312-y.

16. Gloude NJ, Jodele S, Teusink-Cross A, Grimley M, Davies SM et al. Combination of High-dose
Methylprednisolone and Defibrotide for veno-occlusive disease in pediatric hematopoietic stem cell transplant recipients. 2018;24(1):9195. Available from: https://doi.org/10.1016/j. bbmt.2017.09.007.

17. Lia G, Giaccone L, Leone S, Bruno B. Biomarkers for Early Complications of Endothelial Origin After Allogeneic Hematopoietic Stem Cell Transplantation: Do They Have a Potential Clinical Role? Front Immunol. 2021;12:641427. Available from: DOI 10.3389/fimmu.2021.641427.

18. Khosla J, Yeh AC, Spitzer TR, Dey BR. Hematopoietic stem cell transplant-associated thrombotic microangiopathy: current paradigm and novel therapies. Bone Marrow Transplant. 2018;53(2):129-137.

19. Jodele S. Complement in Pathophysiology and Treatment of Transplant-Associated Thrombotic Microangiopathies. Semin Hematol. 2018;55(3):159-166. Available from: DOI 10.1053/j.seminhematol.2018.04.003.

20. Dvorak CC, Higham C, Shimano KA. Transplant-Associated Thrombotic Microangiopathy in Pediatric Hematopoietic Cell Transplant Recipients: A Practical Approach to Diagnosis and Management. Front Pediatr. 2019;7:133.

21. Jodele S, Davies SM, Lane A, Khoury J, Dandoy $C$ et al. Diagnostic and risk criteria for HSCT-associated thrombotic microangiopathy: a study in children and young adults. Blood. 2014;124(4):645-53.

22. Young JA, Pallas CR, Knovich MA. Transplant-associated thrombotic microangiopathy: theoretical considerations and a practical approach to an unrefined diagnosis. Bone Marrow Transplant . 2021;56(8):1805-17.

23. Dandoy $C E$, Rotz $S$, Alonso PB, Klunk A, Desmond $C$ et al. A pragmatic multi-institutional approach to understanding transplant-associated thrombotic microangiopathy after stem cell transplant. Blood Adv. 2021;5(1):1-11.

24. Uderzo C, Bonanomi S, Busca A, Renoldi M, Ferrari $P$ et al. Risk factors and severe outcome in thrombotic microangiopathy after allogeneic hematopoietic stem cell transplantation. Transplantation. 2006;82(5):638-44.

25. Jodele, S., Laskin, B.L., Goebel, J., Khoury, J.C., Pinkard, S.L., Carey, P.M. and Davies, S.M. Does early initiation of therapeutic plasma exchange 
improve outcome in pediatric stem cell transplant-associated thrombotic microangiopathy? Transfusion, 2013;53: 661-667.

26. Gavriilaki E, Sakellari I, Anagnostopoulos A, Brodsky RA. Transplant-associated thrombotic microangiopathy: opening Pandora's box. Bone Marrow Transplant. 2017;52(10):1355-1360. Available from: DOI 10.1038/bmt.2017.39.

27. Worel N, Greinix HT, Leitner G, Mitterbauer M, Rabitsch $W$ et al. ABO-incompatible allogeneic hematopoietic stem cell transplantation following reduced-intensity conditioning: close association with transplant-associated microangiopathy. Transfus Apher Sci. 2007;36(3):297-304.

28. Zhang R, Zhou M, Qi J, Miao W, Zhang Z, Wu $D$ and Han Y. Efficacy and Safety of Eculizum$\mathrm{ab}$ in the Treatment of Transplant-Associated Thrombotic Microangiopathy: A Systematic Review and Meta-Analysis. Front. Immunol. 2021;11:564647. Available from: DOI 10.3389/ fimmu.2020.564647.

29. Jodele S, Dandoy CE, Lane A, Laskin BL, Teusink-Cross $A$ et al. Complement blockade for TA-TMA: lessons learned from a large pediatric cohort treated with eculizumab. Blood. 2020;135(13):1049-1057.

30. Higham CS, Collins G, Shimano KA, Melton A, Kharbanda $S$ et al. Transplant-associated thrombotic microangiopathy in pediatric patients: pre-HSCT risk stratification and prophylaxis. Blood Adv. 2021;5(8):2106-2114.

31. Lucchini G, Willasch AM, Daniel J, Soerensen J, Jarisch A et al. Epidemiology, risk factors, and prognosis of capillary leak syndrome in pediatric recipients of stem cell transplants: a retrospective single-center cohort study. Pediatric Transplantation. 2016;20:1132-1136. Available from: DOI 10.1111/petr.12831.
32. Spitzer TR. Engraftment syndrome following hematopoietic stem cell transplantation. Bone Marrow Transplant 2001; 27: 893-8982.

33. Maiolino A, Biasoli I, Lima J, Portugal AC, Pulcheri W, Nucci M. Engraftment syndrome following autologous hematopoietic stem cell transplantation: definition of diagnostic criteria. Bone Marrow Transplant 2003; 31: 393-397.

34. Schmid I, Stachel D, Pagel P, Albert MH. Incidence, predisposing factors, and outcome of engraftment syndrome in pediatric allogeneic stem cell transplant recipients. Biol Blood Marrow Transplant. 2008; 14: 438-444.

35. Mutahar E, Al-Anazi KA. Engraftment Syndrome: An Updated Review. J Stem Cell Biol Transplant. 2017; Vol.1 No.3:16.

36. Spitzer TR. Engraftment syndrome: double-edged sword of hematopoietic cell transplants. Bone Marrow Transplant. 2015;50(4):46975. Available from: DOI 10.1038/bmt.2014.296.

37. Cornell RF, Hari P, Drobyski WR. Engraftment Syndrome after Autologous Stem Cell Transplantation: An Update Unifying the Definition and Management Approach. Biol Blood Marrow Transplant. 2015;21(12):2061-2068. Available from: DOI 10.1016/j.bbmt.2015.08.030.

38. Fan K, McArthur J, Morrison RR, Ghafoor S. Diffuse Alveolar Hemorrhage after pediatric hematopoietic stem cell transplantation. Frontiers in Oncology. 2020;10:1757. Available from: DOI 10.3389/fonc.2020.01757.

39. Altmann T, Slack J, Slatter MA, O'Brien C, Cant $A$ et al. Endothelial cell damage in idiopathic pneumonia syndrome. Bone Marrow Transplantation. 2018;53:515-518. Available from: https:// doi.org/10.1038/s41409-017-0042-z 